\title{
IbM Pengembangan Produk Cokelat Couverture dengan Penambahan Pangan Fungsional di Desa Randualas Kecamatan Kare Kabupaten Madiun
}

\author{
Achmad Ridwan Ariyantoro ${ }^{1}$, Choirul Anam ${ }^{1}$, Kawiji ${ }^{1}$, Slamet Minardi ${ }^{2}$, Fitriyah Zulfa ${ }^{3}$, \\ Didik Purnomo $^{3}$, Eny Muzayana ${ }^{3}$, Rohmat Priya Atmaja $^{3}$, Clysna Widiatmoko ${ }^{3}$ \\ ${ }^{1}$ Program Studi Ilmu Teknologi Pangan, Fakultas Pertanian UNS \\ ${ }^{2}$ Program Studi Ilmu Tanah, Fakultas Pertanian UNS \\ ${ }^{3}$ Program Studi D2 THP PDD UNS Madiun \\ *Coresponding Author: ridwan030586@gmail.com
}

\begin{abstract}
ABSTRAK
Kabupaten Madiun memilih kakao sebagai salah satu komoditi utama yang bisa dikembangkan karena dinilai tepat dengan struktur tanah di lereng pegunungan dan sebagai daerah tujuan wisata. Petani kakao Desa Randualas, Kecamatan Kare, Kabupaten Madiun memiliki permasalahan yaitu harga jual biji kakao masih rendah sehingga perlu peningkatan nilai jual dengan membuat produk olahan dari biji kakao menjadi produk makanan seperti cokelat couverture. Disamping itu, pengembangan produk berbahan dasar cokelat perlu penganekargaman dengan penambahan pangan fungsional sehingga bermanfaat bagi kesehatan. Target pengabdian masyarakat ini adalah peningkatan kemampuan petani kakao untuk pengembangan produk cokelat couverture dengan penambahan pangan fungsional yang berupa tepung kacang kedelai sehingga meningkatkan pendapatan petani kakao. Kegiatan yang dilakukan adalah sosialisasi, penyuluhan, pelatihan dan praktek proses produksi cokelat couverture yang meliputi pelatihan pembuatan, proses dan pengemasan produk. Hasil pengabdian ini meningkatnya pengetahuan petani dalam mengolah cokelat dengan penambahan pangan fungsional.
\end{abstract}

Kata kunci: cokelat couverture, pangan fungsional, pengabdian masyarakat

\section{ABSTRACT}

Madiun Regency chose cocoa as one of the main commodities which could be developed because it was appropriate with the soil structure on the slopes of the mountains and as a tourist destination. Randualas Village cocoa farmers, Kare Subdistrict, Madiun Regency have a problem that is the selling price of cocoa beans is still low, so it needs to increase the selling value by making processed products from cocoa beans into food products such as chocolate couverture. Besides that, the development of chocolate-based products needs to be improved with the addition of functional food so that it has benefits for human health. The target of community service was to increase the ability of cocoa farmers to develop couverture chocolate products by adding functional food with soybean flour for increase the income of cocoa farmers. The activities carried out were the socialization, counseling, training and practice of the couverture chocolate production process which includes training on process and packaging of products. The community service resulted in an increase in farmers' knowledge in processing chocolate with the addition of functional food.

Keywords: community service, couverture chocolate, functional Food

\section{PENDAHULUAN}

Kakao merupakan salah satu komoditas perkebunan yang peranannya sangat penting bagi perekonomian nasional khususnya bagi penyedia lapangan kerja, sumber pendapatan dan devisa negara. Perkebunan kakao di Indonesia mengalami perkembangan pesat dalam kurun waktu 20 tahun terakhir dan pada tahun 2002, areal perkebunan kakao Indonesia 
tercatat seluas 941.051 ha. Perkebunan kakao tersebut sebagian besar $(87,4 \%)$ dikelola oleh rakyat dan selebihnya $6,0 \%$ dikelola perkebunan besar negara serta $6,7 \%$ perkebunan besar swasta. Menurut data statistik perkebunan Indonesia, komoditas kakao pada 2013-2015 dengan volume produksi mencapai 1.355 ton per tahun. Sedangkan, perkebunan kakao Kabupaten Madiun seluas 5.761 ha dengan sebagian besar dikelola masyarakat (Badan Pusat Statistik Propinsi Jawa Timur, 2016).

Kabupaten Madiun memilih kakao sebagai salah satu komoditi utama. Banyaknya masyarakat yang tinggal di daerah tepian hutan dan daerah-daerah lereng gunung Wilis, maka dipilihlah tanaman kakao sebagai komoditas yang bisa dikembangkan karena dinilai tepat dengan struktur tanah yang ada. Petani kakao desa Randualas telah mendapatkan penyuluhan tentang peningkatan mutu biji kakao dengan fermentasi namun harga jual biji kakao fermentasi dan tanpa fermentasi tidak berbeda sehingga perlu peningkatan nilai jual dengan membuat produk olahan dari biji kakao fermentasi menjadi produk makanan atau minuman seperti cokelat batang, permen, dan bubuk cokelat (cocoa powder). Selama ini hasil biji kakao petani belum pernah diolah menjadi makanan atau minuman cokelat. Pengembangan produk berbahan dasar cokelat sangat penting untuk meningkatkan pendapatan masyarakat dan menjadikan Kecamatan Kare sebagai daerah tujuan wisata.

Salah satu produk olahan cokelat adalah cokelat couverture yang dibuat dari bahan baku biji dan lemak kakao. Cokelat merupakan kategori makanan yang mudah dicerna oleh tubuh dan mengandung banyak vitamin seperti vitamin A1, B1, B2, C, D dan E serta beberapa mineral seperti fosfor, magnesium, zat besi dan juga tembaga (Spillane, 1995). Cokelat juga mengandung antioksidan yang bermanfaat dalam mencegah kerusakan oksidatif yang disebabkan radikal bebas sehingga mencegah terjadinya berbagai macam penyakit seperti penyakit kardiovaskuler, jantung koroner, kanker, serta penuaan dini (Sambadaedi, 2011).

Konsumsi cokelat semakin meningkat sejalan dengan arus globalisasi dan daya beli masyarakat sehingga diperlukan penganekargaman atau modifikasi produk cokelat untuk meningkatkan daya jualnya. Penganekaragaman produk coklat memiliki tujuan untuk menghasilkan produk fungsional yang bermanfaat untuk mengatasi masalah kesehatan dengan menambahkan pangan fungsional dalam proses pembuatan cokelat.

Pangan fungsional lokal yang bisa ditambahkan dalam proses pembuatan cokelat misalnya daun kelor yang telah diteliti banyak mengandung zat gizi dan ditetapkan WHO sebagai 'miracle tree' karena banyak manfaat bagi kesehatan. Biji-bijian seperti kacang hijau dan kacang kedelai juga bisa ditambahkan karena banyak mengandung sumber protein. Pangan lokal lain misalnya buah-buahan dalam bentuk kering maupun serbuk dapat ditambahkan mengingat banyak manfaatnya bagi kesehatan.

Sedangkan, sumber pangan fungsional di Madiun sebagai sumber protein nabati adalah kedelai yang banyak dikonsumsi oleh hampir seluruh lapisan masyarakat Indonesia, sehingga berperan dalam mendukung ketahanan pangan dan meningkatkan status gizi masyarakat (Salim, 2012). Kedelai mengandung protein 35\%, bahkan pada varietas unggul kadar proteinnya dapat mencapai 40 - $43 \%$ (Cahyadi, 2007). Dari uraian tersebut diatas, pengabdian ini sangat penting untuk memberikan ilmu pengetahuan dan ketrampilan dalam olahan produk cokelat kepada masyarakat Desa Randualas sehingga dapat meningkatkan perekonomian masyarakat.

\section{METODE}

Pemecahan permasalahan petani kakao Desa Randualas dapat dilakukan dengan metode pelaksanaan kegiatan pengabdian masyarakat sebagai berikut :

1. Sosialisasi dan penyuluhan

Materi sosialisasi ini berupa proses pengolahan cokelat mulai dari biji, fermentasi hingga menjadi produk cokelat yang siap dikonsumsi. Materi pertama ini disampaikan oleh ahli cokelat dari Program studi Ilmu Teknologi Pangan (ITP) UNS, Dimas Rahadian Aji Muhammad Ph.D. Sedangkan materi kedua berupa materi pemasaran produk cokelat oleh pakar dari ITP UNS, Bara Yudhistira M.Sc.

2. Pelatihan pembuatan cokelat couverture Pelatihan pembuatan cokelat couverture dilakukan dengan menghadirkan dosen yang telah mempunyai pengalaman dan menguasai teknologi dalam proses pembuatan cokelat. Proses pelatihan dilakukan di laboratorium program studi D2 Teknologi Hasil Pertanian, PDD UNS, Kabupaten Madiun karena yang telah memiliki mesin pengolah cokelat. 
Petani kakao sebagai peserta pelatihan menghadiri setiap sesi pengolahan biji kakao menjadi cokelat couverture selama satu hari. Seluruh bahan pelatihan disiapkan oleh pelatih.

3. Pelatihan pembuatan cokelat couverture dengan penambahan pangan fungsional berupa tepung kedelai

Pada tahap awal pembuatan cokelat couverture peserta diminta menyiapkan atau pengikuti prosedur pembuatan tepung kedelai. Kemudian bubuk yang telah jadi dimasukkan dalam proses conching. Hasil Pelatihan pembuatan cokelat couverture yang telah dikeluarkan dari mesin ball mill dilanjutkan pada mesin conching dan ditambahkan dengan penambahan bubuk kedelai. Setelah proses ini selesai dilanjutkan dengan proses tempering, pencetakan, pengemasan.

\section{HASIL DAN PEMBAHASAN}

Permasalahan yang utama dari mitra adalah kelompok tani Desa Randualas hanya menjual biji cokelat tanpa adanya proses fermentasi dan masih kurangnya pengetahuan bagaimana cara membuat produk cokelat yang siap dikonsumsi. Sehingga untuk mengatasi permasalahan mitra tersebut, kami melakukan beberapa kegiatan untuk memberikan solusi kepada mitra. Dari berbagai macam kegiatan yang sudah dilakukan oleh tim pengabdi diharapkan dapat mengatasi segala permasalahan yang ada di dalam mitra yaitu kelompok tani Desa Randualas, Kecamatan Kare, Kabupaten Madiun. Adapun kegiatan yang sudah dilakukan adalah sebagai berikut :

\section{Sosialisasi dan penyuluhan}

Berkaitan dengan masalah yang ada di institusi mitra, program pertama yang kami lakukan adalah melakukan dan mengadakan kegiatan sosialisasi dan penyuluhan kepada mitra yang terdiri dari kelompok tani Desa Randulas. Peserta sebanyak 20 orang hadir dalam kegiatan sosialisasi tersebut yang bertempat di Aula Balai Desa Randualas. Dalam kegiatan tersebut diisi dengan 2 materi utama, yaitu sosialiasi proses pasca panen dan pengolahan cokelat dan proses pemasaran produk cokelat.

Materi pertama tentang sosialiasi proses pasca panen dan pengolahan cokelat disampaikan oleh pakar cokelat nasional yang juga dosen Program Studi Ilmu Teknologi Pangan Fakultas Pertanian UNS, yaitu Dimas Rahadian Aji Muhammad, Ph.D., seperti tertera dalam Gambar 1. Dalam materi yang disampaikannya, peserta mendapat materi berupa asal mula cokelat, istilah istilah dalam bidang cokelat, perbedaan cacao, cocoa, choco mas, choco fat dan lain-lain serta bagaimana proses pasca panen dan proses pembuatan cokelat. Disamping itu, disampaiakan pula bagaimana proses fermentasi biji cokelat dan juga bagaimana pengaruh proses fermentasi terhadap kualitas cokelat yang dihasilkan.
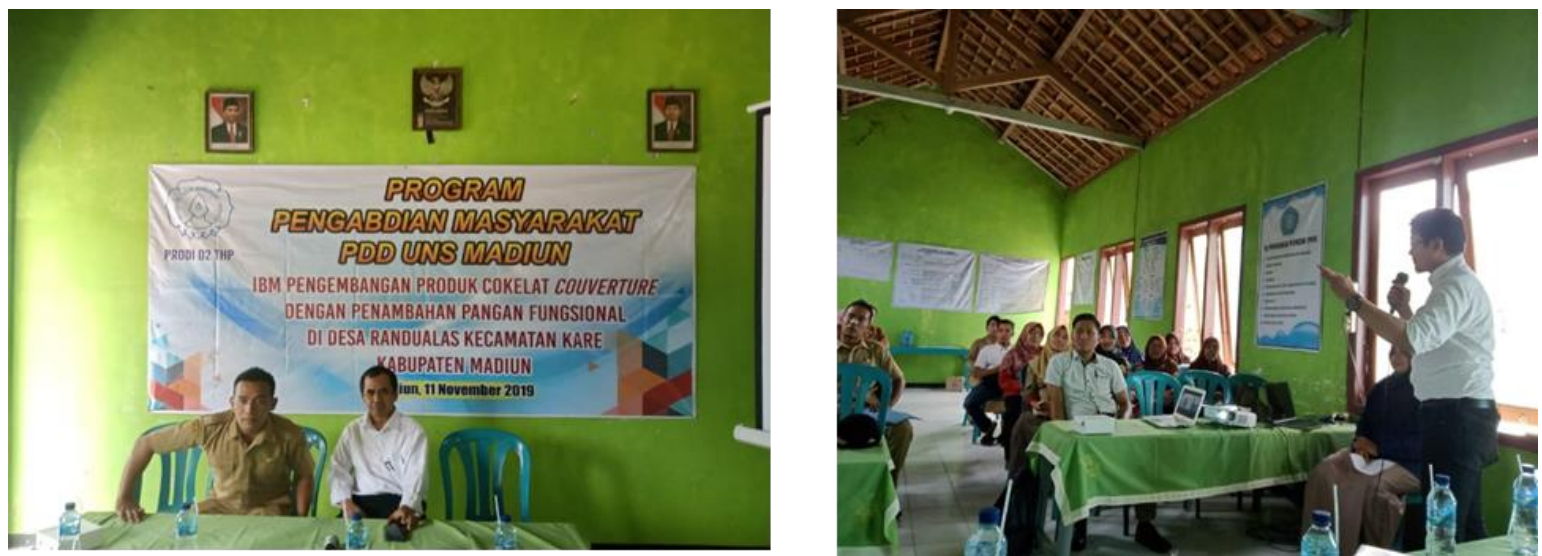

Gambar 1. Kegiatan sosialisasi dan penyuluhan kepada kelompok tani Desa randualas oleh Pakar Cokelat dan juga sekaligus dosen FP UNS, Dimas Rahadian Aji Muhammad S.TP., M.Sc., Ph.D

Materi kedua berupa sosialisasi pemasaran produk cokelat. Materi ini dibawakan oleh Bara Yudistira, M.Sc. yang juga staf pengajar di Program Studi Ilmu Teknologi Pangan, Fakultas Pertanian UNS. Dalam materinya, disampaikan bahwa bagaimana kiat- 
kiat dalam memasarkan produk hasil pertanian, dan cokelat termasuk didalamnya. Juga disampaikan tentang untuk meningkatkan semangat berwirausaha agar pendapatan ekonomi keluarga menjadi meningkat.

\section{Pelatihan teknik proses produksi cokelat couverture dan cokelat dengan penambahan tepung kedelai}

Setelah dilakukan kegiatan yang berupa sosialisasi dan penyuluhan terkait proses pembuatan cokelat dan cara memasarkan produk, peserta dari mitra diundang ke Kampus PDD UNS Madiun di Mejayan, Kabupaten Madiun. Peserta sejumlah 10 orang wanita tani yang merupakan perwakilan dari hasil kegiatan pengabdian yang pertama yang berupa sosialisasi dan penyuluhan. Kegiatan ini dilakukan di laboratorium Praktek Produksi bekerjasama dengan Program Studi D2 Teknologi Hasil Pertanian, PDD UNS Madiun. Laboratorium ini dipilih karena memiliki peralatan yang lengkap terkait dengan proses pembuatan cokelat mulai dari penyangraian, ball milling, conching dan pencetakan cokelat.

Kegiatan ini diawali dengan pemberian materi dari dosen D2 THP PDD UNS Madiun yaitu Fitriyah Zulfah, M.Si. dan Didik Purnomo, S.P. Pembicara pertama yaitu Fitriyah Zulfah, M.Si. memberikan materi proses pembuatan cokelat yang diperkaya dengan bubuk kedelai sebagai pangan fungsional. Pemateri pertama ini memberikan materi terkait prosedur atau tata cara proses pembuatan cokelat yang diperkaya dengan bubuk kedelai sebagai pangan fungsional. Biji cokelat fermentasi yang telah kering disangrai terlebih dahulu selama beberapa waktu sebelum dilakukan proses pemastaan. Proses penyangraian bisa menggunakan alat sangrai atau menggunakan wajan tanah liat untuk menyangrai biji cokelat. Penyangraian merupakan tahap awal proses produksi makanan dan minuman cokelat dan bertujuan untuk membentuk aroma dan citarasa khas cokelat dari biji kakao. Penyangraian dilakukan pada suhu $115-120^{\circ} \mathrm{C}$ selama 20 menit menggunakan mesin sangrai.

Biji cokelat yang sudah tersangrai, kemudian dimasukkan ke dalam alat pemastaan untuk menghasilkan pasta cokelat. Alat ini mempunyai prinsip seperti proses penggilingan yang menyebabkan dinding-dinding sel daging biji cokelat pecah dan cairan lemak keluar dari dalam biji sehingga daging biji yang semula padat menjadi cairan kental yang disebut pasta kakao. Alat pemasta cokelat ini mirip seperti alat penggiling daging, dimana biji cokelat dimasukkan ke dalam alat, dan alat tersebut mendorong biji cokelat hingga hancur dan mengubah menjadi pasta cokelat.

Setelah biji cokelat diubah menjadi pasta cokelat, proses berikutnya adalah ball milling. Proses ball milling ini menggunakan alat yang berupa ball mill. Ball Mill adalah nama mesin pencampur dan penghalus partikel adonan pasta coklat. Mesin ini ada bola-bola besi di dalamnya yang jumlahnya dua kali lipat berat kapasitas mesin. Fungsi bola-bola ini menggilas dan mengecilkan ukuran partikel pasta sehingga sesuai standar Internasional yaitu 20 mikron, sehingga coklat bisa diterima di dalam maupun luar negeri. Proses ini membutuhkan waktu hingga 24 jam dengan suhu $60^{\circ} \mathrm{C}$. Pada proses ini ditambahkan pula lemak cokelat, gula halus, pasta cokelat dan susu full cream. Bahan-bahan lain diperlukan untuk meningkatkan cita rasa dari produk cokelat yang akan dihasilkan.

Proses berikutnya dari pembuatan cokelat adalah proses conching. Fungsi conching adalah untuk menghomogenkan adonan cokelat dengan menambahkan bahan lain seperti ekstrak vanili, lesitin, dan soda kue. Fungsi lesitin adalah sebagai emulsifier sehingga adonan menyatu (air dan minyak/lemak). Dalam proses ini, juga bisa ditambhakn bubuk kedelai sebagai bahan pangan fungsional, sehingga cokelat yang dihasilkan kaya akan protein dan bermanfaat bagi kesehatan.

Proses conching ini membutuhkan waktu selama 2 jam dengan suhu $40^{\circ} \mathrm{C}$. Langkah selanjutnya adalah tempering atau penurunan suhu pasta sehingga mencapai suhu $27^{\circ} \mathrm{C}$ supaya tidak timbul butiran-butiran di permukaan cokelat. Agar cokelat yang dihasilkan cepat memadat bisa disimpan dalam freezer dengan waktu tertentu. Setelah dilakukan pendinginan, proses selanjutnya adalah pencetakan. Pencetakan sebaiknya diatas meja marmer yang mampu mempertahankan suhu pasta. Pengemasan bisa menggunakan dengan kertas aluminium foil atau kertas kuning mengkilap.

Gambar 2 menunjukkan Didik Purnomo,S.P. menyampaikan terkait hal teknis bagaimana menghasilkan biji cokelat yang baik untuk proses pembuatan cokelat. Didik Purnomo juga mengemukakan bahwa biji cojlelat yang difermentasi mempunyai kelebihan yang baik dari segi kualitas jika dibandingkan biji cokelat tanpa fermentasi. Dimana ini menjadi permasalahan di institusi mitra karena kelompok 
tani hanya biasa menjual biji tanpa fermentasi sehingga harganya tidak terlalu tinggi dibandingkan dengan biji fermentasi. Sehingga materi ini sangat bagus dan relevan terkait dengan permasalah yang ada di institusi mitra.
Diharapkan dengan materi ini, institusi mitra dapat meningkatkan pendapatan ekonominya dengan menjual biji cokelat yang sudah terfermentasi. Hasil cokelat yang dibuat disajikan dalam Gambar 3.
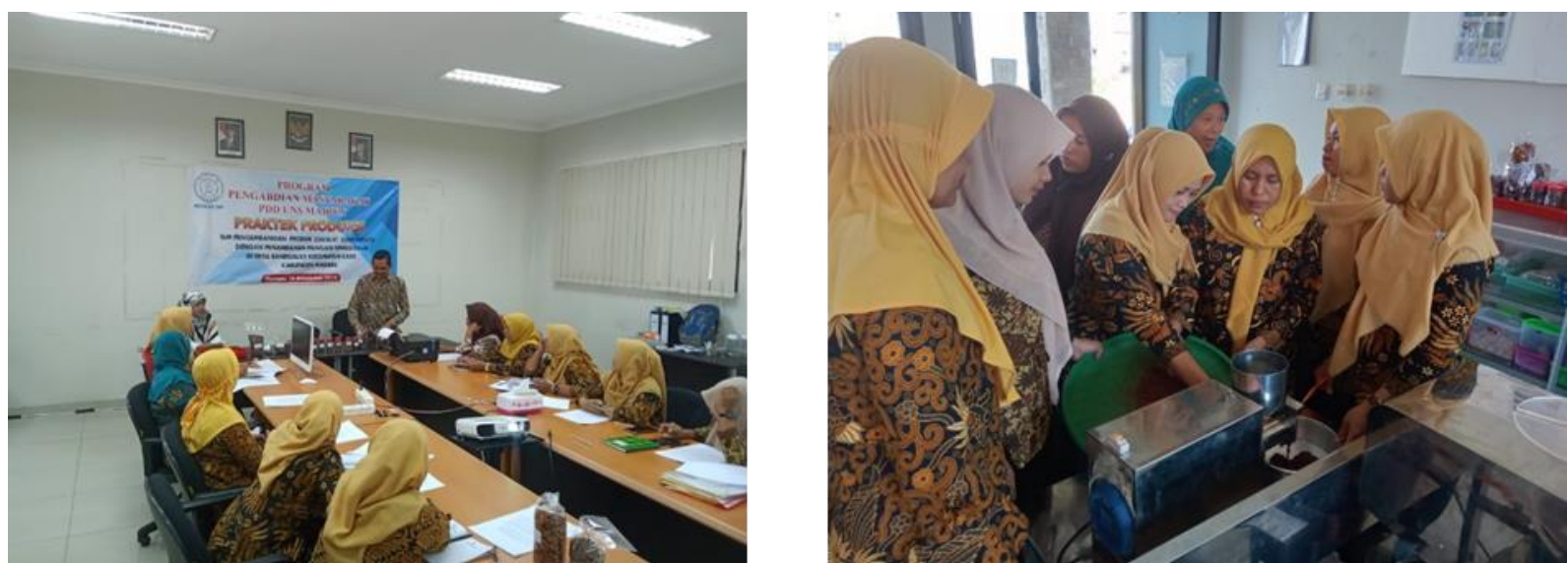

Gambar 2. Kegiatan penyampaian materi dan praktek produksi proses pembuatan cokelat kedelai dari Didik Purnomo,S.P. selaku dosen D2 THP PDD UNS Madiun.

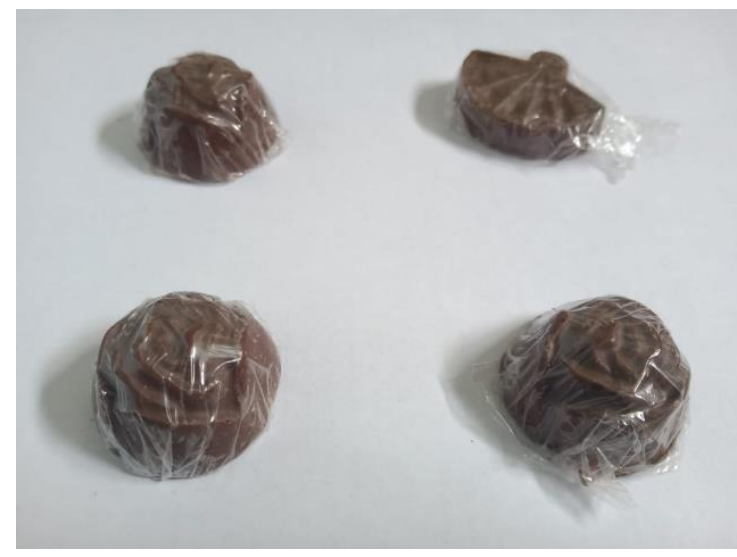

Gambar 3. Hasil produk cokelat courverture dalam program pengabdian ini.

\section{Monitoring dan evaluasi}

Pengabdian masyarakat ini juga melakukan monitoring dan evaluasi setelah dilakukan serangkain kegiatan sebelumnya. Proses monitoring dan evaluasi ini dilakukan dengan melibatkan dosen dari PDD UNS Madiun agar proses monitoring lebih efektif dan efisien karena lebih dekat dengan lokasi institusi mitra. Monitoring dilakukan dengan mengevaluasi sejauh mana kelompok tani Desa randualas mempraktekkan semua materi yang diberikan dan juga apakah sudah bisa menghasilkan produk cokelat yang siap untuk dikonsumsi. Disamping itu, juga dilakukan pendampingan terhadap kelompok tani agar tujuan pengabdian masyarakat ini dapat tercapai dengan baik. Hasil monitoring dapat dilihat pada Tabel 1.
Tabel 1 menunjukkan bahwa hasil monitoring program kegiatan pegabdian masyarakat ini menghasilkan hasil yang cukup baik. Dari beberapa kegiatan yang sudah dilakukan menghasilkan tingkat pemahaman masyarakat yang lebih baik setelah dilakukan pengabdian dan sebelum pengabdian. Hal ini tampak terlihat saat sosialisasi dan praktek produksi dimana sebagian besar peserta baru tahu informasi tersebut seperti cara memanen cokelat yang baik dan bagaimana melakukan proses fermentasi biji cokelat serta proses pengolahan biji cokelat menjadi produk cokelat yang siap untuk dikonsumsi. Disamping itu, harga biji cokelat sebelum program pengabdian hanya sekitar $\mathrm{Rp} \quad 23.000 / \mathrm{kg}$ dikarenakan masyarakat belum mengerti betul bagaimana memilihi biji cokelat yang baik dan proses 
fermentasi biji cokelat. Setelah diadakan program pengabdian dan masyarakat sudah paham bagaimana memilihi biji cokelat yang baik dan pross fermentasi yang baik, sehingga harga biji cokelat menjadi naik menjadi Rp
$28.000 / \mathrm{kg}$. Dengan kenaikan harga jual biji cokelat tersebut, maka program pengabdian masyarakat ini berhasil untuk meningkatkan pendapatan petani cokelat di Desa Randualas, Kecamatan Kare, Kabupaten Madiun.

Tabel 1. Hasil monitoring pra dan pasca program pengabdian

\begin{tabular}{clcc}
\hline No. & Kegiatan & \multicolumn{2}{c}{ Tingkat pemahaman masyarakat } \\
\cline { 3 - 4 } & & Pra & Pasca \\
\hline 1 & Cara memanen biji cokelat yang baik & Belum mengerti & Sudah Mengerti \\
2 & Cara fermentasi biji cokelat & Belum mengerti & Sudah Mengerti \\
3 & Cara menyangrai biji cokelat & Belum mengerti & Sudah Mengerti \\
4 & Cara mem-ball milling cokelat & Belum mengerti & Sudah Mengerti \\
5 & Cara men-conching cokelat & Belum mengerti & Sudah Mengerti \\
6 & Cara mencetak cokelat & Belum mengerti & Sudah Mengerti \\
7 & Cara mengemas cokelat & Belum Mengerti & Sudah mengerti \\
\hline
\end{tabular}

\section{KESIMPULAN}

Permasalahan dari institusi mitra atau kelompok tani Desa Randualas, Kecamatan Kare, Kabupaten Madiun ini antara lain banyak petani yang hanya menjual biji cokelat tanpa dilakukan fermentasi sehingga harga jualnya lebih rendah dari biji cokelat yang terfermentasi. Selain itu masalah lainnya adalah kurangnya ilmu pengetahuan dan teknis terkait proses pasca panen biji cokelat dan proses pembuatan cokelat yang siap dikonsumsi. Dari permasalah tersebut, tim pengabdi memberikan solusi berupa kegiatan sosialisasi dan penyuluhan dengan materi pasca panen dan proses pembuatan coelat serta manajemen pemasaran produk cokelat. Disamping itu, agar kelompok tani memahami dan mengerti bagaimana proses pembuatan cokelat, maka kami diadakan praktek produksi untuk memberikan ilmu dan materi terkait proses pembuatan cokelat. Agar cokelat yang diproduksi oleh kelompok tani mempinyai harga jual yang tinggi, maka kami memberikan materi juga bagaimana membuat produk cokelat kaya akan protein dengan menggunakan bahan berupa bubuk kedelai sehingga cokelat yang dihasilkan bersifat fungsional dan bermanfaat bagi kesehatan.

\section{UCAPAN TERIMA KASIH}

Penulis mengucapkan terimakasih kepada UNS dan Program Studi D2 THP PDD UNS Madiun dalam pendanaan dan pelaksanaan pengabdian masyarakat ini.

\section{DAFTAR PUSTAKA}

Badan Pusat Statistik Propinsi Jawa Timur. (2016). Jawa Timur dalam angka 2016. Retrieved September 10, 2019, from http://jatim.bps.go.id/

Cahyadi, W. (2007). Teknologi dan Khasiat Kedelai. Jakarta: Bumi Aksara.

Salim, E. (2012). Kiat Cerdas Wirausaha Aneka Olahan Kedelai. Yogyakarta: Lily Publisher.

Sambadaedi. (2011). Antioksidan dan Radikal Bebas. Retrieved July 24, 2019, from https://edhisambada.wordpress.com/2011/ 02/22/antioksidan-dan-radikal-bebas/

Spillane, J. J. (1995). KOMODITI KAKAO, Peranannya Dalam Perekonomian Indonesia. Yogyakarta: Kanisius. 